\title{
Seasonal Dynamics of Agro-meteorological Drought in Mberengwa and Zvishavane Districts between 2017 and 2020, Zimbabwe
}

\author{
Oshneck Mupepi ( $\square$ omupepi@gmail.com ) \\ Midlands State University Faculty of Social Sciences \\ Mark M Matsa \\ Midlands State University Faculty of Social Sciences
}

\section{Research Article}

Keywords: Spatio-temporal dynamics, Drought, Drought resilience, Agro-meteorological, Drought severity

Posted Date: November 10th, 2021

DOI: https://doi.org/10.21203/rs.3.rs-1013365/v1

License: (ㄷ) (i) This work is licensed under a Creative Commons Attribution 4.0 International License. Read Full License

Version of Record: A version of this preprint was published at Natural Hazards on March 7th, 2022. See the published version at https://doi.org/10.1007/s11069-022-05294-y. 


\section{Abstract}

Drought severity is increasing in Southern Africa which is affecting rain-fed agriculture, the main source of livelihood in most countries in this region. The study assessed the seasonal spatio-temporal dynamics of agro-meteorological drought between 2017 and 2020 in Mberengwa and Zvishavane Districts. An empirical research design supported by quantitative geographical information system and remote sensing techniques was adopted in this study. Microsoft excel 2013, SPI generator and ArcMap 10.5 software were used for data analysis in this study. Results showed that both Mberengwa and Zvishavane Districts experienced an increasing trend in spatial coverage of drought from 2017 to 2019 before a slight decline in 2020. From 2017, drought severity increased in terms of spatial coverage with this spatial distribution increasing to almost over $3 / 4$ of the wards in both Mberengwa and Zvishavane Districts between 2018 and 2020. Since 2017, on a ward level basis, both districts have been experiencing late onset and early cessation of the rain season as shown by increasingly dry October, November and March, months which determine the length of crop growing season in these two districts. Results indicated that the month of March was drier in Mberengwa whilst the month of December was drier in Zvishavane, an indication of more mid-season dry spells in Zvishavane and earlier rainfall cessation in Mberengwa. Drought is worsening in both Mberengwa and Zvishavane Districts hence long term drought resilience interventions are required to improve drought resilience of communities in these areas. The study recommends the Government of Zimbabwe and other stakeholders of drought resilience building like CARE International, World Vision among others to prioritize launching of resilience building initiatives in most vulnerable areas whilst guided by fine empirical information on spatial distribution of drought.

\section{Introduction}

Understanding climatic variability is critical for improving long-term forecasting of severe events such as droughts through informed quantification of mechanisms connected to the hydrological cycle (Massei and Fournier, 2012; Räsänen and Kummu, 2013). Droughts present negative influence on society, the environment, and the economy. Drought is a natural occurrence which can be exacerbated by climate change. However, with global warming and population expansion, drought resilience is projected to decline in the future. Drought, unlike other climatic dangers such as floods, tornadoes, and hurricanes, is a slow-moving phenomenon that can develop without notice and last for months (Sheffield and Wood 2011). Drought affects agriculture, water supplies, and the environment if the climate system's water deficit exceeds a particular level that cannot sufficiently support anthropogenic and environmental requirements. Meteorological drought is defined by precipitation deficits whilst agricultural drought is caused by soil moisture deficits (Keyantash and Dracup, 2002). This indicates that drought occurs when precipitation or moisture supply is insufficient to support a specific requirement or use.

Major efforts have been made in the last decades to understand the dynamics of drought intensity and frequency, either by using teleconnection concepts to find relationships between climate and drought indices or by using teleconnection concepts to find relationships between climate and drought indices (Santos et al., 2010; AghaKouchak, 2015; Mazdiyasni and AghaKouchak, 2015; Xu et al., 2015).

Comprehensive and reliable drought monitoring is becoming increasingly important to aid drought planning and mitigation. This is mainly because the frequency and severity of droughts are expected to increase as a result of climate change (Wilhelmi and Wilhite, 2002; Keyantash and Dracup, 2004; Zhou et al., 2012; Halwatura et al., 2017). Droughts have traditionally been defined and analyzed using point measurements from networks of meteorological stations. The widely used Standardized Precipitation Index (SPI), for example, is based on ground-based precipitation observations and is the World Meteorological Organization's (WMO) approved indicator for meteorological drought (Hayes et al., 1999; McKee et al., 1993). SPI spans time periods ranging from one to twenty-four months or more. Many international experts and officials from national meteorological and hydrological services across the world recognizes the SPI as a universal meteorological drought index for effective drought monitoring and climate risk management (Yoon and Wood, 2012; Batisani, 211). However, in areas where drought is mainly driven by water loss through high temperature induced evapotranspiration, SPI is unreliable as it fails to incorporate this aspect (Yoon and Wood, 2012). Therefore, remote sensing has been adopted by many studies to monitor drought through detecting vegetation response to soil moisture deficit and temperature related stress, which covers the weakness of SPI. Through this technique, the impact of evapotranspiration and temperature are completely considered as vegetation is sensitive to changes in moisture as a result of high temperature and associated evapotranspiration. Recently, global and near-real-time remote sensing data have opened the way to thoroughly describing drought conditions regionally and globally, particularly in locations with limited sample gauges (Jiao et al., 2019; Lu et al., 2016; Rhee et al., 2010; Wang et al., 2012; Wu et al., 2013; Zhang et al., 2017). To assess drought conditions, many drought indices based on remote sensing measurements have been created.

Remote sensing provides a new perspective for drought monitoring, supplementing the in situ-based climatic data that has historically been utilized for this purpose (Brown et al., 2008). Repeat coverage of spatially continuous data gathered in a systematic and objective way is provided by space borne sensors. Drought indices based on remote sensing are extensively utilized because satellite data is a faster, less costly, and more efficient tool for drought monitoring than observational data (Dalezios et al., 2014). Moderate resolution imaging spectroradiometer (MODIS), Landsat and National oceanic and atmospheric administration-Advanced very high-resolution radiometer (NOAA- AVHRR) satellite series are examples of satellites with sensors that operate in a variety of spectral bands and are widely used in drought monitoring (Tsirois et al., 2004; Pieiro et al., 2006; Zeng et al., 2014). Many drought monitoring models have been developed using various satellite data and they are based on satellite derived vegetation indices (VIs) encompassing the Normalised Difference Vegetation Index (NDVI), Vegetation Condition Index (VCI) and Temperature Condition Index (TCI) among others (Brown et al., 2008). 
Vegetation health $(\mathrm{VH})$ based records obtained from NOAA global monitoring satellite were used to monitor drought in the United States and results indicated that drought reappears every 9 years in western US (Kogan, 2013; Kogan and Guo, 2016). Rahimzadeh et al. (2008) successfully used NOAA AVHRR derived VCI, NDVI and SPI to determine spatial and temporal dynamics of drought from 1997 to 2001 in North-West Iran. Another study on micro-level agricultural drought in Parulia district in India between 2000 and 2016 was conducted by Palchaudhuri and Biswas (2019) using VCl and NDVI derived from MODIS satellite and SPI. Berhan (2011) used NOAA AVHRR satellite to derive VCI and NDVI to monitor drought conditions over Ethiopia between 1982 and 2004. Sirdas and Sen (2003) applied only the SPI to determine the spatio-temporal dynamics of drought in Trakya, in Turkey. In Zimbabwe, Frischen et al. (2020) used NOAA derived VCI, NDVI and Vegetation health indices to detect drought severity over the country between 1989 and 2019. Based on this literature it can be noted that majority of studies that used remote sensing indices adopted NOAA and MODIS satellites which have course resolution which were suitable for monitoring drought at regional and country levels. These cannot provide finer information when decisions are to be made at local level especially within districts. Therefore, this study adopts Landsat satellite platform with finer spatial resolution $\left(30 \mathrm{~m}^{2}\right.$ ) to derive $\mathrm{TCl}$ and $\mathrm{VCl}$ indices for local (ward level) level drought monitoring in Mberengwa and Zvishavane districts.

Therefore, this study seeks to: 1) map seasonal spatial and temporal dynamics of agricultural and meteorological droughts and 2) assess ward level precipitation variability between 2017 and 2020 in Mberengwa and Zvishavane Districts. Mberengwa and Zvishavane Districts are arid-semi-arid areas where drought has been affecting crop and livestock production despite being major sources of livelihood for communities in these areas. Given increasing drought severity and incidence nation-wide, it was found significant to measure the extent of drought spatial severity in these aridsemi arid districts. The 2017-2020 period was considered because this is the period when the Enhancing Community Resilience and Inclusive Market Systems project was launched by CARE International to build community resilience to drought in Mberengwa and Zvishavane Districts hence it was imperative to measure drought risk for the purpose of assisting the project to make informed implementation of resilience building initiatives. This detailed analysis of drought at ward level is fundamental in informing drought resilience building stakeholders so that they implement resilience building projects with an appreciation of the spatial and temporal distribution of drought within districts. This will aid attainment of Sendai Framework target 1 and two of reducing disaster related deaths and property loss respectively and Sustainable development goal 1 and 2 of reducing hunger and poverty respectively. This will aid in Zimbabwe's quest to meet the national development strategy goal of achieving an Upper Middle Income status by 2030 .

\section{Study Area}

The research was carried out in the neighbouring districts of Zvishavane and Mberengwa in Midlands province, at an elevation of 1,039 meters above sea level. The two districts have total areas of $5066 \mathrm{~km} 2$ and $2476 \mathrm{~m} 2$, respectively (Zimbabwe national population statistics, 2012). According to FAO (2016), Zimbabwe's overall area is 390760 km2, making Mberengwa and Zvishavane districts 1.93 percent of Zimbabwe's total size.

Zvishavane is 97 kilometers west of Masvingo, on the major Bulawayo-Masvingo route (20 $20^{\prime} \mathrm{S}$; $\left.30^{\circ} 02^{\prime} \mathrm{E}\right)$, while Mberengwa is about 24 kilometers south of Zvishavane ( $\left.20^{\circ} 29^{\prime} 0^{\prime \prime} \mathrm{S}, 29^{\circ} 55^{\prime} 0^{\prime \prime} \mathrm{E}\right)$. Both districts are located in agro-ecological zones 4 and $5 \mathrm{a}$, respectively receiving $450-650 \mathrm{~mm}$ and less than $650 \mathrm{~mm}$ of annual rainfall and an annual average temperature of about $28^{\circ} \mathrm{C}$ (Manatsa et al., 2020). High temperatures in these locations cause increased evapotranspiration, which increases the occurence of agricultural droughts. Due to the unpredictable nature of precipitation in these regions, seasonal moisture deficits and severe mid-season dry spells are prevalent, resulting in increased agro-meteorological drought occurrences.

These soils require a constant supply of moisture to maintain agricultural production; yet, the unpredictable and sparse rainfall makes crop and animal production a risk, since moisture and pasture requirements for crops and cattle are seldom satisfied. The geology of the area is linked to the Great Dyke, which consists of layered mafic intrusions linked to economically important metals such as platinum, chromium, nickel, vanadium, copper, titanium, iron, and tin, providing alternative livelihood sources for communities in these areas through mining activities (Badlock et al., 1991)

According to the Zimbabwe Central Statistical Office (CSO) 2012 last national census report, Zvishavane has a population of 52734 people, with 27 815 women and 24919 men, whilst Mberengwa has a population of 185,757 people, with males accounting for 86,764 and females accounting for 98,993. Mining is one of the primary economic sources of living in Zvishavane and Mberengwa (Zimbabwe Poverty Assessment Study Survey Summary, 2003 ). Despite the obstacles of shifting climatological circumstances, rural people in both districts continue to grow cash crops such as cotton, sunflowers, maize, sorghum, and vegetables, as well as livestock raising for sustenance.

Due to erratic or unreliable precipitation in Mberengwa and Zvishavane districts, agriculture is vulnerable as communities depend on rainfall for crop and livestock production. This leaves the majority vulnerable to food insecurity and starvation emanating from frequent crop failures and livestock deaths mainly due to water scarcity. However, large deposits of minerals such as platinum, gold and asbestos which exist in Zvishavane and gold, tantalite and emeralds which are abundant in Mberengwa provide alternative livelihood through employment in mining companies as well as involvement in small scale and artisanal mining activities.

\section{Methodology}

This research adopted an empirical research design, which is based on the use of verifiable evidence to arrive at research conclusions. In this study GIS and remote sensing based scientific data collection methods and available precipitation records made it easy to scientifically confirm the spatiotemporal dynamics of drought (Borry et al., 2006). The computation of Vegetation Condition Index (VCl) and Temperature Condition Index (TCl) with 
ArcMap 10.5 software, as well as the calculation of the Standardized Precipitation Index (SPI) using the SPI generator software constituted scientific methods which provided scientific evidence of drought. These mathematically computed indices allowed for the determination of agricultural and meteorological droughts in Mberengwa and Zvishavane districts between 2017 and 2020.

Landsat images with a spatial resolution of $30 \mathrm{~m}^{2}$ were acquired from the United States Geological Survey (USGS) website for the period 1990 to 2020. Landsat 5 images were downloaded for the period 1990-2014 and Landsat 8 images were downloaded for the period 2015 to 2020 . Images for the period 1990-2016 were considered during computation of $\mathrm{VCl}$ and $\mathrm{TCl}$ for the purpose of ensuring comparison of drought conditions over a long time period which would give a reliable signal of the influence of climate change on drought conditions. Therefore the multi-year NDVI and brightness temperature used during $\mathrm{VCl}$ and $\mathrm{TCl}$ computation was for 30 years which was significant to indicate deviation of 2017, 2018, 2019 and 2020 drought conditions from the long-term (1990-2020) normal.

Table 1

Satellite data sets used and their meta-data

\begin{tabular}{|llllll|}
\hline Period & Satellite platform & $\begin{array}{l}\text { Resolution } \\
\text { (meters) }\end{array}$ & Path & Row & Date \\
\hline $1990-2014$ & Landsat 5 TM & 30 & 170 & 74 & March \\
\hline $2015-2020$ & Landsat 8 OLI & 30 & 170 & 74 & March \\
\hline Source: Authors & & & & \\
\hline
\end{tabular}

These Landsat images were used for the computation of $\mathrm{NDVI}, \mathrm{VCl}$ and $\mathrm{TCl}$ for characterisation of agricultural drought. Images for the month of March were used for drought monitoring because maximum chlorophyll in vegetation and croplands is experienced in March when peak growth is attained (Yang et al., 2015; Alemayehu et al., 2017) hence deviations from normal vegetation condition during this month would be a reliable depiction of drought due to moisture deficit even during the previous months.

Removal of the no data value region and conduction of geometric and radiometric corrections to remove distortions and radiometric noise constituted the pre-processing stage (data cleaning). Mberengwa and Zvishavane district shapefiles were created and used to extract study areas from Landsat images. Some researchers who studied drought (Di et.al, 1994; John et.al, 1998) employed NDVI to monitor vegetation status that shows whether there is drought or not. Use of NDVI is based on differences in spectral responses of health and unhealthy vegetation. Healthy vegetation reflects less in the visible electromagnetic spectrum due to chlorophyll absorption in this region while it reflects more in the near infrared spectrum due to internal reflectance of the mesophyll spongy tissue of healthy green leaf. In contrast, stressed vegetation reflects more in the visible electromagnetic spectrum and less in the near infrared spectrum (Campbell, 1987). These differences in spectral response by both drought stressed and healthy vegetation assists determining drought and its spatial extent. NDVI can be calculated as the ratio of red and the NIR bands of a sensor system and is represented by the following equation:

NDVI $=$ NIR -RED.

NIR+ RED

Where RED and NIR are reflectance in the red and near infrared bands respectively. Due to difficulties in accurately interpreting NDVI values in heterogeneous terrains (Kogan, 1987) as the case in both Zvishavane and Mberengwa districts and the weakness that NDVI doesn't clearly show the weather impact separately, $\mathrm{VCl}$ as suggested by Kogan (1997) was adopted in this research. Calculated NDVI was used to compute VCl in this research.

Vegetation condition index was first suggested by Kogan (1993) to indicate the status of vegetation cover as a function of maximum and minimum NDVI experienced in a specific area over a specific period of time. Vegetation condition presented by $\mathrm{VCl}$ was in the form of percentage with values ranging from $0-100 \%$. Values form $50-100 \%$ indicate optimum to above normal conditions yet values close to $0 \%$ signify extremely dry conditions. These values assisted in determining agrometeorological drought severity in different areas of Mberengwa and Zvishavane Districts as they showed how much vegetation has responded to climate. Vegetation condition index was computed as:

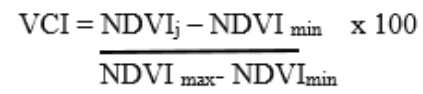

Where $\mathrm{NDVI}_{\mathrm{j}}$ is current year NDVI, $\mathrm{NDVI}_{\text {min }}$ is multi-year minimum NDVI and $\mathrm{NDVI}_{\text {max }}$ is multi-year maximum NDVI.

According to Thenkabail et.al (2004), temperature condition index was suggested by Kogan (1997) to reflect vegetation response to temperature. When using $\mathrm{TCl}$, higher temperature corresponds to severe drought conditions, moderately high temperatures corresponds to mild drought and 
optimum temperatures correspond to normal conditions. In this research TCI was used to confirm drought conditions detected using VCl and SPI. TCI was computed as:

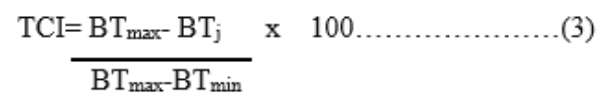

Where $\mathrm{BT}$ is the brightness temperature, $\mathrm{BT}_{\text {max }}$. is multi-year maximum brightness temperature, $\mathrm{BT}_{\text {min }}$ is multi-year minimum brightness temperature and $\mathrm{BT}_{\mathrm{j}}$ is current year brightness temperature. Maximum and minimum $\mathrm{BT}$ was calculated basing on long-term records of remote sensing images for particular periods. Low TCl values indicate hot weather conditions and high values show milder conditions.

The Standardised Precipitation Index (SPI) was developed by Mckee et.al (1993) for characterisation of drought. SPI is the number of standard deviations that the observed value would experience from the long term mean of a normally distributed random variable. SPI was used to quantify monthly meteorological drought conditions between 2017 and 2020. Six-month SPI (SPI-6) was be adopted in this research to incorporate all months within rainfall season (October -March) in Zimbabwe. This SPI was computed using 1990-2020 monthly precipitation records obtained from the Meteorological Services Department. The standardised precipitation index (SPI) was computed using the SPI generator software. The Standardised Precipitation Index was computed as:

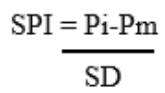

$\mathrm{SD}$

Where $\mathrm{Pi}$ is seasonal precipitation, $\mathrm{Pm}$ is the seasonal mean and SD is the standard deviation of the long-term record.

Spatial and temporal severity of drought in both Zvishavane and Mberengwa districts was analysed in ArcMap 10.5 software using raster calculator and spatial analyst tools to produce $\mathrm{VCl}$ and $\mathrm{TCl}$ thematic maps showing the distribution of drought in Zvishavane and Mberengwa districts. The raster calculator and cell statistics tools were used to compute $\mathrm{TCl}$ and $\mathrm{VCl}$ for characterising drought conditions. Microsoft excel 2013 was used to analyse drought coverage statistics and creation of graphs for presentation of seasonal drought area coverage between 2017 and 2020.

\section{Results}

\subsection{Seasonal dynamics of agro-meteorological drought in Mberengwa and Zvishavane districts between 2017 and 2020}

The study indicated that drought conditions in Mberengwa and Zvishavane districts were not constant between 2017 and 2020 . VCl and TCl values indicated dynamics in spatial severity of drought across these four years.

\subsubsection{Vegetation Condition Index based drought spatial severity between 2017 and 2020 in Mberengwa and Zvishavane districts.}

Vegetation condition index values indicated that most of Mberengwa (65.1\%) and Zvishavane (81.7\%) area was under mild-no drought conditions in 2017 (Figure 3). Both Mberengwa and Zvishavane districts had $18.2 \%$ and $11.6 \%$ of their area respectively under moderate drought conditions whereas $16.6 \%$ and $6.6 \%$ of their area was under severe to extreme drought conditions. This indicated that the area under drought conditions was smaller than area under mild-no drought conditions. However, despite both districts being dominated by mild-no drought conditions, Mberengwa had more area under drought compared to Zvishavane. In 2018, area under mild-no drought condition in Mberengwa declined to $44.5 \%$ and in Zvishavane it declined to $52.5 \%$. The area under moderate drought conditions increased to $24.1 \%$ in Mberengwa and $27.2 \%$ in Zvishavane whereas area that experienced severe drought conditions increased to 31.4\% in Mberengwa and 20.3\% in Zvishavane in 2018. Overall, Zvishavane had more area under drought conditions than Mberengwa in 2018.

In 2019 area under severe to extreme severe drought conditions in Mberengwa and Zvishavane districts further increased to 48\% and 35.2\% respectively. For both districts, area under mild-no drought conditions declined to $25.2 \%$ and $35 \%$, that is, for Mberengwa and Zvishavane districts respectively. In Mberengwa, area under moderate drought increased to $26.9 \%$ whereas in Zvishavane it increased to $29.8 \%$ (Figure 3 ).

Overall, most of the area experienced drought in both districts with Mberengwa having more of its area under drought conditions compared to Zvishavane(Figure 3). In 2020, area under severe to extreme drought conditions increased to $57.1 \%$ in Mberengwa and $69 \%$ in Zvishavane. This was accompanied by decline in area under moderate and mild-no drought conditions in both Districts. For Mberengwa District, area under mild-no drought and moderate drought conditions declined to $20 \%$ and $22.8 \%$ respectively whilst in Zvishavane it declined to $13 \%$ and $18 \%$ respectively. In general, Zvishavane had more area under drought conditions compared to Mberengwa but both were dominated by severe to extremely severe drought conditions. This indicated that drought incidence has been increasing in both Mberengwa and Zvishavane districts from 2017 to 2020.

4.1.2 Temperature Condition Index based drought spatial severity between 2017 and 2020 in Mberengwa and Zvishavane districts. 
In terms of Temperature Condition Index, in 2017, Mberengwa District had 30.4\% of its area under mild-no drought conditions whilst for Zvishavane it was $19 \%$ of the total area. In Mberengwa District, $58.3 \%$ of the area was under moderate drought conditions whilst only $11.3 \%$ was under severeextreme drought condition and in Zvishavane, 38.9\% of the area was under moderate drought and $42.1 \%$ was under severe-extreme drought conditions. Both districts were dominated by drought in 2017 but Mberengwa was dominated by moderate drought whereas Zvishavane was dominated by severe to extreme drought. In 2018, both districts experienced a decline in area under mild-no drought conditions, that is, $20.5 \%$ in Mberengwa and $15.8 \%$ in Zvishavane (Figure 4).

For Mberengwa District, area under moderate drought conditions dropped to $30.6 \%$ and in Zvishavane it dropped to $35.4 \%$ of the total area (Figure 4). However, area under severe-extreme drought conditions increased to $48.9 \%$ in Mberengwa and $48.8 \%$ in Zvishavane. In general, during this year (2018), area under drought increased in both districts compared to 2017. In 2019, both Mberengwa and Zvishavane districts experienced an increase in area under severe to extreme drought conditions which dominated in these two districts as indicated by $88.4 \%$ and $86 \%$ respectively. TCl values confirmed a drop in both area under mild-no drought and moderate drought conditions in Mberengwa District (7.3\% and 4.3\% respectively) and Zvishavane District (9.3\% and $4.7 \%$ respectively). In 2020, area under severe-extreme drought conditions decreased in both districts, that is, $49.6 \%$ in Mberengwa District and $72.4 \%$ in Zvishavane District. Compared to 2019, area under mild-no drought condition and that under moderate drought condition increased in both districts. In Mberengwa, area that experienced mild-no drought conditions increased to $23.9 \%$ and that under moderate drought increased to $26.5 \%$ whereas in Zvishavane, area that experienced mild-no drought and moderate drought conditions increased to $9.3 \%$ and $14.6 \%$ respectively. Overall, thermal drought condition pattern indicated an increase in area being affected by drought though some fluctuations existed during the study period.

\subsection{Spatial dynamics of drought in Mberengwa and Zvishavane districts between 2017 and 2020}

Between 2017 and 2020, both Mberengwa and Zvishavane districts were dominated by thermal stress and drought conditions increased in spatial coverage over this period. In 2017, both $\mathrm{TCl}$ and $\mathrm{VCl}$ indicated mild to no drought conditions in some parts of ward 32,31 and 29 to the south west, parts of ward 35 to the west, eastern parts of ward 5 and 20 to the east of Mberengwa District. Same conditions were detected in some parts of ward 17 to the south east, and wards 1, 2 and parts of ward 4 to the north of Zvishavane District. Severe -extreme drought conditions were indicated in wards 34 and parts of ward 32 to the south west, parts of ward 35 and ward 1 to the west, parts of ward 4 to the north east and most of ward 2 to the north of Mberengwa District. Same conditions were confirmed by both indices in parts of ward 18 to the south east, some parts of wards 5,6 and 7 to the west and some parts of wards 8, and 10 at the central part of Zvishavane District.

Both $\mathrm{TCl}$ and $\mathrm{VCl}$ indicated moderate drought conditions in some parts of ward 5 to the north east, parts of wards 7,8 and 18 close to the center, wards 33, 15 and 16 to the south of Mberengwa District. In Zvishavane, parts of ward 4 to the north and some parts of ward 19 to the south of the District experienced moderate drought conditions. Mild to normal conditions were shown by both indices in southern parts of ward 35 to the east, parts of wards 29, 30, 31 and eastern parts of ward 32 to the south west of Mberengwa District. Same conditions were also confirmed in some parts of wards 1, 2 and 4 to the north, north eastern parts of ward 4 and parts of ward 17 to the south east of Zvishavane District (Figure 5).

However, severe-extreme thermal stress conditions were detected by TCl in wards 4, 6, and western parts of ward 20 to the east, ward 22 to the south east, wards 25 and 26 to the south and ward 36 to the north west of Mberengwa District (Figure 5). For Zvishavane, all western wards and most areas around the center and south of the District were confirmed to be under severe-extreme thermal stress conditions. This indicates that there was a lot of thermal stress than moisture deficit in these areas as VCl indicated mild-no drought conditions over the same areas.

In 2018, both indices indicated severe-extreme drought conditions in most parts of central Mberengwa including wards $8,9,17,10,12$, some parts of wards 18 and 16 . Ward 2 and 3 to the north, eastern parts of ward 34, wards 14 and 30 , southern parts of ward 29 and some parts of ward 31 to the south west experienced severe-extreme drought. More so, southern parts of ward 4 to the north east and southern parts of ward 21 to the east of Mberengwa experienced severe-extreme drought conditions as well. For Zvishavane, both indices indicated that eastern parts of ward 2, northern parts of ward 4 and most of wards 3 and 8 to the north and wards 7 and 10 close to the center of the district were in severe-extreme drought conditions. Moderate drought conditions were detected by both indices in the eastern parts of ward 3 to the north, parts of ward 5 to the north east, some parts of wards 19, 28 and 23 to the south east, northern parts of ward 12 and other parts of ward 11 and 1 to the east of Mberengwa District. For Zvishavane both indices indicated moderate drought conditions in parts of ward 2 and parts of ward 9 to the north, some parts of ward 4 to the east, ward 17 and some parts of ward 18 to the south east of the District. Both indices confirmed mild-no drought conditions in some parts of wards 29,31 and 33 to the south west of Mberengwa District.

However, most south eastern and western parts of Mberengwa experienced more thermal stress than moisture deficit stress as TCl indicated more severe drought conditions in these areas. This was also the case with most western and eastern wards of Zvishavane where severe to extreme drought conditions were detected more by $\mathrm{TCl}$ whereas $\mathrm{VCl}$ detected mild and moderate drought conditions, an indication of more thermal stress than water deficit stress. In 2019, both indices agreed in detecting severe-extreme drought conditions in southern Mberengwa (wards 16, 15, 28, 33, 26 and 23). Severe-extreme drought conditions were detected by both $\mathrm{TCl}$ and VCl in the west (wards 1, 35,37, parts of wards 11 and 12), parts of ward 36 to the north east, wards 2 and 3 to the north and parts of wards 6 and 5 to the north east of Mberengwa. Both indices also indicated severeextreme drought conditions in northern parts of Zvishavane (wards 1, 2, parts of ward 4 and northern parts of ward 8). Wards 17, 18 and most of

Page 6/19 
ward 16 in south eastern Zvishavane were also under severe-extreme drought conditions. Both indices indicated mild-no drought conditions in southern parts of ward 7, northern parts of ward 12 and some few areas at the central part of the District.

However, TCl indicated severe-extreme thermal conditions in almost all wards to the east (wards 6, 19, 20 and 21), north east (northern parts of ward 6 and ward 5) and south east (wards 24 and 22) of Mberengwa which indicates that these areas were in more of thermal stress condition than moisture deficit related stress as indicated by VCl indicating moderate drought conditions in the same areas. This was also the case with western parts of ward 2 to the north, parts of wards 17, 10 and 12 and other parts of ward 11 at the center of Mberengwa District. In Zvishavane, higher thermal stress was confirmed in all western wards $(5,11,8$ and ward 7$)$ and southern wards (ward 19, western parts of ward 15 and southern parts of ward 14) where $\mathrm{VCl}$ confirmed them to be under mild-no drought conditions.

For 2020, both indices indicated severe-extreme drought conditions in most parts of both Mberengwa and Zvishavane districts. All wards to the west $(1,11,13$, greater western part of ward 34 and western parts of ward 35), south west (western parts of ward 32), east (wards $5,6,19,20$, parts of ward 21 and 22) and south (33, 15, parts of ward 16 and ward 27) of Mberengwa District experienced severe-extreme drought conditions in 2020 as agreed by both $\mathrm{TCl}$ and $\mathrm{CVI}$ values. In Zvishavane, both $\mathrm{TCl}$ and $\mathrm{VCl}$ indicated severe-extreme drought conditions in the south (greater part of ward 19 and ward 15), all wards at the center $(10,13,12)$, to the east (ward 14, southern part of ward 9), some areas to the west (parts of ward $3,5,6$ and 11 ) and south east (ward 18 and western parts of ward 17). Domination of moderate drought conditions was indicated in wards 35,23, most of ward 29, parts of wards 30 and 34 of Mberengwa District and wards 1, 2, some parts of ward 4 and ward 17 of Zvishavane District. Some areas that experienced mild-no drought conditions were detected in other parts of wards 35, 29, 23 and some parts of ward 9 in Mberengwa and few areas in wards 1 and 2 of Zvishavane.

However, TCl detected severe-extreme drought conditions in most parts of ward 2, greater parts of wards 7 and 4 , wards 25 and 28 where $\mathrm{VCl}$ detected less severe drought conditions. This shows that these wards were under more thermal stress than moisture deficit stress. This was the case with western wards of Zvishavane which were detected to be wholly covered with severe-extreme drought conditions by TCl whilst VCI indicated a mixture of severe-extreme and moderate drought conditions. Overall, both indices indicated an increase in spatial coverage of drought in both districts between 2017 and 2020 though thermal stress indicated to have affected both districts more in 2019 and 2020.

\subsection{Seasonal temporal dynamics of meteorological drought between 2017 and 2020 in Mberengwa and Zvishavane Districts.}

Results indicated significant temporal dynamics of meteorological drought between 2017 and 2020 (Table 2). Zvishavane District experienced a better start of the 2017/18 season followed by moderately dry conditions at the midst of the season in December. However, February and March were extremely wet and near normal respectively. For Mberengwa a comparatively late onset of rain was indicated by extremely dry October though moderately wet to normal conditions were experienced between November and February. However, early cessation of rain was shown as the month of March was extremely dry. When comparing the two districts meteorologically, Zvishavane experienced better conditions with longer rain season than Mberengwa which experienced late onset and early cessation of rain as indicated by very dry month of October and March.

Table 2

Seasonal temporal distribution of meteorological drought in Mberengwa and Zvishavane based on SPI-6

\begin{tabular}{|c|c|c|c|c|c|c|c|c|c|c|c|c|c|}
\hline \multirow[t]{2}{*}{ SEASON } & \multicolumn{7}{|c|}{ ZVISHAVANE } & \multicolumn{6}{|c|}{ MBERENGWA } \\
\hline & ОСТ & NOV & DEC & JAN & FEB & MAR & & ОСТ & NOV & DEC & JAN & FEB & MAR \\
\hline $2017 / 18$ & 0.21 & 1.27 & -1.03 & -0.62 & 2.66 & 0.34 & & -2.99 & 1.12 & 0.39 & -0.42 & 2.55 & -2.90 \\
\hline 2018/19 & -3.30 & -1.32 & -1.33 & -1.35 & 1.38 & -1.33 & & -0.25 & -0.99 & -0.42 & -0.68 & 1.62 & -1.82 \\
\hline \multirow[t]{3}{*}{$2019 / 20$} & -3.50 & -0.76 & -2.09 & -0.62 & -0.75 & -1.34 & & -2.99 & -0.21 & -1.74 & -0.51 & -0.01 & -2.21 \\
\hline & & & & & KEY & & & & & & & & \\
\hline & & & $\begin{array}{l}\text { Extremely } \\
\text { dry }\end{array}$ & $\begin{array}{l}\text { Severely } \\
\text { dry }\end{array}$ & $\begin{array}{l}\text { Moderately } \\
\text { dry }\end{array}$ & $\begin{array}{l}\text { Near } \\
\text { normal }\end{array}$ & $\begin{array}{l}\text { Moderately } \\
\text { wet }\end{array}$ & $\begin{array}{l}\text { Very } \\
\text { wet }\end{array}$ & $\begin{array}{l}\text { Extremely } \\
\text { wet }\end{array}$ & & & & \\
\hline
\end{tabular}

For the 2018/19 season, Zvishavane was drier than Mberengwa as indicated by late start of the season in Zvishavane followed by very little precipitation between November and January with only the month of February receiving better precipitation as shown by moderately wet conditions (Table 2). For Mberengwa, the season was better as indicated by near normal conditions between October and January followed by very wet conditions in February. Both districts experienced early rainfall cessation as indicated by moderately dry and very dry March in Zvishavane and Mberengwa Districts respectively. During the 2019/20 season both districts were dominated by severe meteorological droughts. Both Districts were characterized by late onset and early cessation of rainfall season as shown by dry October and March. Both districts experienced very dry conditions in December. For the month of November, January and February, both districts experienced near normal conditions. When comparing the two districts between 2017 and 2020, the Month of March was drier in Mberengwa whilst the month of December was drier in Zvishavane, an indication of more 
mid-season dry spells in Zvishavane and earlier rainfall cessation in Mberengwa. Overall, inter and intra-seasonal meteorological droughts are evident in both Districts.

\section{4 Ward level seasonal precipitation variability between $2017 / 2019$ and $2019-2020$ seasons.}

Based on long term monthly average precipitation for Mberengwa and Zvishavane Districts (1990-2020 average), the study determined deviation of monthly precipitation received in each ward from the long term monthly mean. Based on these averages, how much each ward deviated from this average was determined through subtracting precipitation received in each ward from this average which indicated positive values for higher-thannormal precipitation and negative values for below normal precipitation (Table 3). Therefore, in this study, 1990-2020 average for each month was considered normal which was used as reference for comparison purpose. Zvishavane town was not considered because there were no precipitation records specifically for this area. However, the study was mainly concerned with non-urban wards where agriculture is being carried out.

Table 3

October and November meteorological condition categorization criteria

\begin{tabular}{|c|c|c|c|c|c|c|}
\hline Month & $\begin{array}{l}\text { 1990-2020 } \\
\text { average }\end{array}$ & $\begin{array}{l}\text { Totally } \\
\text { dry }\end{array}$ & $\begin{array}{l}\text { Severely drier than } \\
\text { normal }\end{array}$ & $\begin{array}{l}\text { Slightly drier than } \\
\text { normal }\end{array}$ & $\begin{array}{l}\text { Normal to slightly wetter } \\
\text { than normal }\end{array}$ & $\begin{array}{l}\text { Severely wetter than } \\
\text { normal }\end{array}$ \\
\hline $\begin{array}{l}\text { October } \\
\text { (Zvishavane) }\end{array}$ & $18.8 \mathrm{~mm}$ & -18.8 & -11 to -18.7 & -0.1 to -10.9 & 0 to $10.9 \mathrm{~mm}$ & $11 \mathrm{~mm}$ and above \\
\hline $\begin{array}{l}\text { October } \\
\text { (Mberengwa) }\end{array}$ & $21.8 \mathrm{~mm}$ & -21.8 & -11 to -21.7 & -0.1 to -10.9 & $0-10.9 \mathrm{~mm}$ & $11 \mathrm{~mm}$ and above \\
\hline $\begin{array}{l}\text { November } \\
\text { (Zvishavane) }\end{array}$ & $70.6 \mathrm{~mm}$ & -70.6 & -21 to -70.5 & -11 to -20.9 & $0-20.9 \mathrm{~mm}$ & $21 \mathrm{~mm}$ and above \\
\hline $\begin{array}{l}\text { November } \\
\text { (Mberengwa) }\end{array}$ & $75.3 \mathrm{~mm}$ & -75.3 & -21 to -75.2 & -0.1 to -20.9 & $0-20.9 \mathrm{~mm}$ & $21 \mathrm{~mm}$ and above \\
\hline
\end{tabular}

Based on this categorization, majority of wards in both Mberengwa and Zvishavane districts were totally dry in October of the 2017/18 season except for wards 2, 6, 11 and 15 in Zvishavane and wards 2, 10, 11, 18, 27 and 28 in Mberengwa which experienced severely drier than average precipitation that used to be received in both districts (Table 3 ).

During the 2018/19 season, all wards in Zvishavane were totally dry except for ward 11 which received precipitation though it was extremely drier compared to the 1990-2020 average (Figure 6). In Mberengwa, during this season, only wards 9, 8, 15, 28 and 29 received precipitation though they were extremely drier compared to the 1990-2020 average for the month of October. For the 2019/20 season only wards 7, 10 and 15 received precipitation but they were severely drier than average for the month of October whilst all other wards were totally dry. In Mberengwa, only wards17, 25,26 and 34 received precipitation though they were within the severely drier than the 1990-2020 average for October category.

For the month of November, during the $2017 / 18$ season, most wards in Zvishavane $(1,5,6,7,8,12,14$ and 18$)$ received precipitation but within the severely drier than normal category and some wards $(3,10,16,17$ and 19$)$ were totally dry (Figure 6$)$. Ward 2 was within the normal to slightly wetter than normal, wards 4 and 8 were slightly drier than normal and wards 11 and 13 were within the severely wetter than normal category. For Mberengwa District, 6 wards (2, 3, 6,7,17 and 32) were severely drier than normal and 3 wards (19, 24 and 34) were slightly drier than normal. Six wards $(11,13,21,25,26$, and 29$)$ were normal to slightly wetter than the 1990-2020 average whereas wards 12,20 and 23 were severely wetter than the 1990-2020 average. All remaining wards in Mberengwa were severely drier than normal during November of this season.

During the 2018/19 season November, all wards in Zvishavane were totally dry except for only ward 7 which received precipitation but within the severely drier than normal category. In Mberengwa, all other wards were totally dry except for wards 2,3,8,9,16,18,20,21,2,25,28,30 and 35 which were severely drier than normal. During November of the 2019/20 season in Zvishavane, wards 5,6, 16, 18 and 19 were totally dry, wards 3 and 15 were slightly drier than normal, ward 11 was severely wetter than normal, ward 13 was slightly wetter than normal whereas the rest were severely drier than normal. In Mberengwa wards 4, 31 and 3 were totally dry, wards 7,10,16, 21,23, 26 and 35 were slightly drier than normal whilst wards 6, 13, 15 and 20 were normal to slightly wetter than normal. Only ward 22 was within the severely wetter than normal category whereas all other wards were severely drier than normal. 
Table 4

December and January meteorological condition categorization criteria

\begin{tabular}{|c|c|c|c|c|c|c|}
\hline Month & $\begin{array}{l}\text { 1990-2020 } \\
\text { average }\end{array}$ & $\begin{array}{l}\text { Totally } \\
\text { dry }\end{array}$ & $\begin{array}{l}\text { Severely drier than } \\
\text { normal }\end{array}$ & $\begin{array}{l}\text { Slightly drier than } \\
\text { normal }\end{array}$ & $\begin{array}{l}\text { Normal to slightly wetter } \\
\text { than normal }\end{array}$ & $\begin{array}{l}\text { Severely wetter than } \\
\text { normal }\end{array}$ \\
\hline $\begin{array}{l}\text { December } \\
\text { (Zvishavane) }\end{array}$ & $129.2 \mathrm{~mm}$ & -129.2 & -21 to -129.1 & -0.1 to -20.9 & 0 to $20.9 \mathrm{~mm}$ & $21 \mathrm{~mm}$ and above \\
\hline $\begin{array}{l}\text { December } \\
\text { (Mberengwa) }\end{array}$ & $129.7 \mathrm{~mm}$ & -129.7 & -21 to -129.6 & -0.1 to -20.9 & 0 to $20.9 \mathrm{~mm}$ & $21 \mathrm{~mm}$ and above \\
\hline $\begin{array}{l}\text { January } \\
\text { (Zvishavane) }\end{array}$ & $133.4 \mathrm{~mm}$ & -133.4 & -21 to -133.3 & -0.1 to -20.9 & 0 to $20.9 \mathrm{~mm}$ & $21 \mathrm{~mm}$ and above \\
\hline $\begin{array}{l}\text { January } \\
\text { (Mberengwa) }\end{array}$ & $115.8 \mathrm{~mm}$ & -115.8 & -21 to -115.7 & -0.1 to -20.9 & 0 to $20.9 \mathrm{~mm}$ & $21 \mathrm{~mm}$ and above \\
\hline
\end{tabular}

Basing on comparison with 1990-2020 average for the month of December in Zvishavane, only ward 1 was slightly wetter whereas wards 8 and 15 were totally dry during the $2017 / 18$ season. All other wards received precipitation but they were within the severely drier than normal category. In Mberengwa, wards 7 and 9 were severely wetter than the 1990-2020 average, wards 35 and 37 were slightly wetter whilst wards $5,10,14$ and 18 were slightly drier than average. All other remaining wards received precipitation but they were severely drier than the 1990-2020 average. For December of the 2018/19 season, all wards in Zvishavane were severely drier than average whereas only ward 15 was totally dry. In Mberengwa, all wards were also severely drier than average whilst ward 19 was totally dry. For the 2019/20 season, during the month of December, all wards in Zvishavane received precipitation but they were severely drier than average except for ward 17 which was slightly drier than normal. During the same month in Mberengwa, wards 3 and 22 were slightly drier than average whilst the rest were severely drier than average.

For the month of January, during the $2017 / 18$ season in Zvishavane, 6 wards (1, 3,4,8,9 and 17) were severely wetter than the $1990-2020$ average and $4(7,10,18$ and 19) were slightly drier (Figure 7$)$. All other wards received precipitation but they were within the severely drier than normal category. For Mberengwa, during the same month, wards 2, 7, 27 and 32 were severely wetter than average whilst wards 1, 5, 16, 17 and 22 were slightly drier than normal. Wards 4 and 9 were slightly wetter than average whilst the remaining were severely drier than normal. During January of the 2018/19 season in Zvishavane, ward 15 was within the severely wetter than average category, wards 5 and 16 were slightly wetter than normal whilst the rest were severely drier than normal. For Mberengwa, ward 4 was totally dry, wards 2,9,15,17,18,24 and 35 were slightly drier than normal whilst all remaining wards were severely drier than normal (Figure 7).

During January of the 2019/20 season in Zvishavane (Figure 7), ward 9 was within the severely wetter than average category, wards 2,4,11 and 16 were within the normal to slightly wetter than average category (Table 5), wards 3 and 8 were slightly drier whilst all other remaining wards were severely drier than average. In Mberengwa, wards 2 and 20 were severely wetter than average, wards 19 and 27 were normal to slightly wetter than average. Wards $1,7,9,15,16,32$ and 33 were slightly drier than average whilst wards 1 and 14 were totally dry during January of the $2019 / 20$ season.

Table 5

February and March meteorological condition categorization criteria

\begin{tabular}{|c|c|c|c|c|c|c|}
\hline Month & $\begin{array}{l}1990-2020 \\
\text { average }\end{array}$ & $\begin{array}{l}\text { Totally } \\
\text { dry }\end{array}$ & $\begin{array}{l}\text { Severely drier than } \\
\text { normal }\end{array}$ & $\begin{array}{l}\text { Slightly drier than } \\
\text { normal }\end{array}$ & $\begin{array}{l}\text { Normal to slightly wetter } \\
\text { than normal }\end{array}$ & $\begin{array}{l}\text { Severely wetter than } \\
\text { normal }\end{array}$ \\
\hline $\begin{array}{l}\text { February } \\
\text { (Zvishavane) }\end{array}$ & $104.0 \mathrm{~mm}$ & -104.0 & -21 to -103.9 & -0.1 to -20.9 & 0 to $20.9 \mathrm{~mm}$ & $21 \mathrm{~mm}$ and above \\
\hline $\begin{array}{l}\text { February } \\
\text { (Mberengwa) }\end{array}$ & $92.3 \mathrm{~mm}$ & -92.3 & -21 to -92.2 & -0.1 to -20.9 & 0 to $20.9 \mathrm{~mm}$ & $21 \mathrm{~mm}$ and above \\
\hline $\begin{array}{l}\text { March } \\
\text { (Zvishavane) }\end{array}$ & $63.9 \mathrm{~mm}$ & -63.9 & -21 to -63.8 & -0.1 to -20.9 & 0 to $20.9 \mathrm{~mm}$ & $21 \mathrm{~mm}$ and above \\
\hline $\begin{array}{l}\text { March } \\
\text { (Mberengwa) }\end{array}$ & $54.3 \mathrm{~mm}$ & -54.3 & -21 to -54.2 & -0.1 to -20.9 & 0 to $20.9 \mathrm{~mm}$ & $21 \mathrm{~mm}$ and above \\
\hline
\end{tabular}

During February of the 2017/18 season in Zvishavane, wards 3, 5,13,14 and 18 were severely drier than the 1990-2020 average, wards 9,11 and 19 were slightly drier and wards 4 and 8 were normal to slightly wetter whereas the rest were within the severely wetter than normal category. For Mberengwa, wards 6, 7, 12, 22,24,25,36 and 35 were severely drier than normal, wards 2, 3, 15, 16, 23 and 33 were slightly drier than normal, and wards $1,8,9,10,14,19,20$ and 21 were severely wetter than normal whilst the remaining were within the slightly wetter than normal category. 
During the 2018/19 season in Zvishavane, majority of wards experienced severely drier than normal conditions (wards 1, 3, 5, 9, 12, 14 and 18) followed by those which experienced slightly drier than normal conditions $(6,10,13,16$ and 17), slightly wetter than average conditions (2,4,8 and 19) and severely wetter than average conditions (7, 11 and 15). For Mberengwa, wards $2,4,9,10,12$ and 13 were moderately to extremely wetter than normal, wards $1,8,35$ and 36 were normal to slightly wetter than normal whilst wards 3,7 and 11 were slightly drier. All remaining wards were severely drier than average during the February of the $2018 / 19$ season. During the $2019 / 20$ season in Zvishavane, ward 16 was within the severely wetter than normal category, wards 15 and 17 were within the normal to slightly wetter than normal category whilst wards 2 and 8 were within the slightly drier than normal category. The remaining majority were severely drier than normal. For Mberengwa, wards 4, 17, 19, 21, 26 and 33 were within the severely wetter than normal category, wards $8,9,10,11$ and 29 were within the normal to slightly wetter than normal category whilst 2,5 , $10,12,14,18,29,31$ and 35 were slightly drier than normal. All remaining wards were severely drier than normal during February of the $2019 / 20$ season.

For the month of March during the 2017/18 season in Zvishavane, wards, 6, 7, 8 and 17 were within the severely wetter than normal conditions, wards 13 and 16 were slightly wetter than normal, wards 3, 4, 9 and 19 were slightly drier than normal whereas the rest were severely drier than normal. In Mberengwa wards 9, 10, 14, 22 and 27 were within the severely wetter than average category, wards 3, 6, 7 and 8 were slightly wetter than normal, wards $2,4,17,22,23,29$ and 31 were slightly drier than normal whilst all remaining wards were severely drier than normal.

For the 2018/2019 season in Zvishavane, wards 6 and 7 were within the severely wetter than normal category, wards 13,14 and 16 were normal to slightly wetter than normal, and wards 3 and 17 were slightly drier than normal whilst the rest were in the severely drier than normal category. For Mberengwa, wards $3,6,10,15,22,29,33,35$ and 36 were within the severely wetter than normal category, wards 4, 5, 7, 9, 16,19, 21 23, 25 and 26 were slightly wetter than normal, wards $1,8,14,27$ and 28 were slightly drier than normal whilst the remaining were within the severely drier than normal category (Figure 8).

During March of the 2019/20 season in Zvishavane, wards 6 and 17 were severely wetter than normal, wards 11 and 12 were slightly drier whilst all other wards were severely drier than normal (Figure 8). For Mberengwa, wards 6, 22 and 27 were within the severely wetter than normal category, wards 3, 7, 23 and 33 were within the normal to slightly wetter than normal category whilst wards 2, 5, 10, 12, 14, 19, 29, 31 and 36 were within the slightly drier than normal category (Figure 8). All the remaining wards were extremely drier than normal for the month of March.

\section{Discussion}

\subsection{Seasonal distribution of drought in Mberengwa and Zvishavane Districts between 2017 and 2020}

Vegetation Condition Index results indicated an increase in drought conditions in both Mberengwa and Zvishavane Districts between 2017 and 2020 (Figure 5). Year 2017 had less moisture stress related drought incidence in most areas within both districts which indicates that precipitation deficit has been increasing from 2017 to 2020 in Southern Zimbabwe including Mberengwa and Zvishavane Districts. One of main reasons that resulted in comparatively less drought in 2017 and 2018 was the LaNina episode of 2017-2018 (NOA, 2021) which resulted in better precipitation compared to years 2019 and 2020 which have been confirmed as El Nino years (FAO, 2019; WMO, 2021).

However, Zvishavane has been experiencing comparatively worse drought conditions than Mberengwa between 2017 and 2020 seasons (Figure 9) which confirms more drought incidence and severity in Zvishavane, a scenario likely to be driven by the dominance of soils of poor moisture retention in Zvishavane (Mupepi and Matsa, 2021). On the other hand, Temperature Condition Index results indicated fluctuations in temperature related stress conditions between 2017 and 2020 (Figure 5). Temperature related stress has been increasing in both districts which signify increasing temperature impacts in Zvishavane and Mberengwa Districts which affected agriculture in most areas.

Overall, both indices showed the dominance of drought in both Mberengwa and Zvishavane Districts except for 2017 when moisture deficit related stress indicated the dominance of non-drought area in both Districts.

Several studies on drought in Zimbabwe confirmed droughts in 2018, 2019 and 2020 (Masante et al., 2019; Frischen et al., 2020, Masante et al., 2020).These studies confirm remotely sensed droughts over this period in Mberengwa and Zvishavane Districts as well since they are usually affected more by droughts that affect Zimbabwe due to their location in agro ecological regions 4 and 5 (Manatsa et al., 2020). The main reason behind high moisture stress in Mberengwa and Zvishavane Districts is high temperatures that are experienced in these semi-arid areas (averaging $28^{\circ} \mathrm{C}$ ) which affect agriculture through evapotranspiration even in good rainfall seasons (Chigumbu, 2015). This is also the main reason why TCl has been indicating more drought coverage in both districts than VCl. This is supported by Kogan (2002) and Winkler et al. (2017) who agreed that TCl shows thermal stress whilst $\mathrm{VCl}$ shows water deficit stress. Therefore variations in drought coverage according to $\mathrm{TCl}$ and $\mathrm{VCl}$ were due to the fact that they indicate vegetation response to temperature and moisture respectively (Kogan, 1987). However, the trajectories in drought conditions indicated by both indices were similar.

\subsection{Seasonal spatio-temporal distribution of drought in Mberengwa and Zvishavane Districts between 2017 and 2020.}

Page $10 / 19$ 
Findings indicated that no wards have been in constantly severe drought conditions in all $(2017,2018,2019$ ad 2020$)$ years, however some experienced extreme drought in three of these years. Wards that experienced severe-extreme drought conditions in three of the study seasons in Mberengwa include wards 1 and 35 (in 2017, 2019 and 2020), ward 16 (in 2018, 2019 and 2020) and ward 34 (in 2017, 2018 and 2020 ). In Zvishavane such wards include ward 8 (in 2017, 2018 and 2019) and ward 10 (in 2017, 2018 and 2020). From a yearly drought incidence analysis these are wards with highest frequency of severe-extreme droughts. This also clearly indicates that drought has been changing in severity from ward to ward between 2017 and 2020 and not all wards were uniformly affected during this period.

In Mberengwa District, wards that experienced severe-extreme drought conditions in two of the 2017-2020 years include wards 2 and 4 (in 2017 and 2018) wards 3 and 12 (in 2018 and 2019), wards 5, 6, 11,15 and 33 (in 2019 and 2020). In Zvishavane, such wards include wards 2 and 4 (in 2018 and 2019), wards 5 and 6 (in 2017 and 2020), and ward 3 (in 2018 and 2020), ward 7 (in 2017 and 2018 ), ward 17 (in 2019 and 2020 ) and ward 18 (in 2017 and 2019). These wards proved to be also more affected compared to other remaining wards which experienced severe-extreme drought conditions only once. When it comes to moderate drought conditions only ward 4 of Zvishavane has been affected three times in 2017,2018 and 2020 whilst wards 5 and 23 have been affected twice, in 2017 and 2018 and in 2018 and 2020 respectively. In Mberengwa, only wards 2 and 17 have been affected twice over this period, in 2018 and 2020. Despite being comparatively better to those wards that suffered severe droughts, generally these wards cannot be left out when counting drought affected areas during this period.

\subsection{Ward level seasonal precipitation variability in Mberengwa and Zvishavane between 2017 and 2020.}

Results showed that only few wards were receiving very little precipitation during the month of October whereas the majority were totally dry between 2017 and 2020, an indication of late onset of the rainfall season in both Mberengwa and Zvishavane Districts. The month of October used to mark the onset of crop planting as it received better amounts of precipitation in previous decades especially during the 2001-2010 decade as indicated by precipitation records from the Meteorological Service Department. Late onset of the rainfall season in both districts worsened during the 2018/19 and $2019 / 20$ seasons with the $2018 / 19$ season being the worst when fewer wards received little precipitation. In general, all wards received insignificant precipitation to support the beginning of rain-fed agriculture in both Mberengwa and Zvishavane Districts. The shifting of rainfall season in Zimbabwe was confirmed by Tadross et al. (2005) who indicated that late onset of rainfall season has been increasing by an average of 2 days per year since 1990s.

The month of November which usually receive precipitation for crop planting in Mberengwa and Zvishavane and other areas in Zimbabwe was far much better compared to October during the $2017 / 18$ season when some wards received more than average precipitation that used to be received in these Districts. November of season $2018 / 2019$ was dry which shows that rainfall season onset was late during this season with majority of wards being totally dry except for ward 11 in Zvishavane and 14 wards $(2,3,8,9,16,18,20,21,24,25,28,30,35$ and 37$)$ in Mberengwa which received precipitation though they were severely drier than the $1990-2020$ average.

However the $2019 / 2020$ season November was better as precipitation was received in a number of wards despite some being totally dry in both districts. The month of December during the 2018/2019 and 2019/2020 was very dry compared to December of the season $2017 / 2018$, a scenario that confirms the impact of El Nino phenomenon on late onset of rainfall and mid-summer dry spells in southern Africa including Zimbabwe (Tadros et al., 2005). However, over 95\% of wards in both Mberengwa and Zvishavane Districts did not receive significant precipitation that could significantly support agriculture during the 2017/18 season. For the next two seasons (2018/19 and 2019/20), December was severely drier than long term average. This signifies that the month of December has become drier during the 2018/19 season, an indication of poor start of the crop growing season in both districts. According to Tadros et al.(2005) late onset of rainfall in Zimbabwe is usually associated with the El Nino phase of the ENSO cycle. In this regards, the 2018/19 season was confirmed as an El Nino year (FAO, 2019; WMO, 2021) which might have resulted in late rainfall onset as well as mid-season dry spells indicated during this year by SPI in this study.

Even during the $2017 / 18$ season which was comparatively better in terms of onset of rainfall season, several wards were severely drier than normal for these two districts. February and March proved to be better rainfall receiving months for both districts, during all three seasons (2017/2018, 2018/2019 and 2019/2020). However, decline in precipitation in March was noted when compared to February of both 2017/2018 and $2019 / 2020$ seasons. This indicates that most wards in both Mberengwa and Zvishavane Districts received poor rainfall in March which shows the possibility of significant impacts on crop production as low rainfall during the month of March in Zimbabwe usually affect crop yields. This is mostly because March is the month when most crops like maize and other cereal crops demand more moisture as they mature.

Drought conditions during October were confirmed by SPI-6 in 2018/2019 and 2019/2020 seasons in Zvishavane and $2019 / 2020$ season in Mberengwa. SPI-6 also confirmed that the $2017 / 2018$ season was wetter than $2018 / 2019$ and $2019 / 2020$ seasons. This was mainly due to the 2018-19 El Nino which was confirmed by the United States Climate Prediction Centre (2019). Manatsa et al. (2020) and Masante at al. (2020) also confirmed drought conditions in Zimbabwe during the 2018/19 season. This drought could not spare agro ecological regions 4 and 5 in which Mberengwa and Zvishavane Districts are located. This concurs with postulations by Sachikonye (1992) who confirmed that Mberengwa and other southern districts of Zimbabwe are more prone to drought and are hardest hit by droughts that affect Zimbabwe.

\section{Conclusion}


The study assessed the seasonal spatio-temporal dynamics of agro-meteorological drought between 2017 and 2020 in Mberengwa and Zvishavane Districts. Between 2017 and 2020, drought in both Mberengwa and Zvishavane Districts experienced an increasing trend from 2017 to 2019 before a slight decline in 2020 . From 2017, drought severity increased in terms of spatial coverage with this spatial distribution increasing to almost over $3 / 4$ of wards in both Mberengwa and Zvishavane Districts between 2018 and 2020. In terms of precipitation distribution since 2017, on a ward level basis, the general pattern indicated late onset and early cessation of the rain season as shown by increasingly dry October, November and March, months which determine the length of crop growing season in these two districts. Results indicated that the month of March was drier in Mberengwa whilst the month of December was drier in Zvishavane, an indication of more mid-season dry spells in Zvishavane and earlier rainfall cessation in Mberengwa. Earlier cessation of rainfall in Mberengwa is due to the fact that the ITCZ which induces precipitation in Zimbabwe moves northwards towards the end of rainfall season which makes Mberengwa which is to the south of Zvishavane stop receiving precipitation earlier than Zvishavane. The dominance of mid-season dry spells in Zvishavane District need a detailed local climatic analysis to confirm these meteorological conditions. Overall, inter and intra-seasonal agro-meteorological droughts are evident in both districts.

\section{Recommendations}

In light of the findings from this study, the following recommendations are suggested:

- Researchers in the field of drought and drought resilience building are encouraged to adopt a hybrid method of drought monitoring which incorporates remote sensing indices and meteorological indices so as to ensure a comprehensive analysis of drought whereby these methods cover each other's weaknesses. This will ensure reliable mapping of drought severity and impacts as well as analysis of nature of droughts affecting communities for which drought resilience is to be built.

- The Government of Zimbabwe is encouraged to introduce climate research centers fully equipped with resources that allow climate parameter analysis and development of new drought monitoring indices that best suits climatological conditions of Zimbabwe. This will enhance innovation and improved climate related disaster management which will culminate into rejuvenation of agriculture as the backbone of the economy thus contributing to achievement of National development strategy goal number one of achieving middle income status by 2030 .

- The Government of Zimbabwe and other stakeholders of drought resilience building like CARE International, World Vision among others are advised to prioritize launching of resilience building initiatives in most vulnerable areas whilst guided by fine information on spatial distribution of drought.

- Mberengwa and Zvishavane communities are advised to adopt and even improve donor initiated drought resilience building initiatives so as to ensure constant strengthening of their adaptive, absorptive and transformative capacities to overcome drought shocks and stressors since drought severity and incidence is experiencing an increasing trend.

- Since findings indicated more drought severity in Zvishavane District than Mberengwa District throughout the study period, drought resilience building stakeholders are encouraged to focus more on initiatives related to enhancement of soil moisture conservation (Supply or production of organic fertilizers and addition of humus content in the soil ) or introduce improved drought tolerant crops in Zvishavane since more agricultural drought in Zvishavane seems to be emanating from poor moisture retention capacity of its sandy Ustalf soils. This can improve water retention capacity of soils for improved crop production under drought conditions.

- Resilience building projects are encouraged to increase intensity of resilience building initiatives in most affected wards rather than providing uniform assistance for all wards including those that are less vulnerable to drought.

\section{Declarations}

Conflict of Interest and Authorship Confirmation Form

- All authors have participated in (a) conception and design, or analysis and interpretation of the data; (b) drafting the article or revising it critically for important intellectual content; and (c) approval of the final version.

- This manuscript has not been submitted to, nor is under review at, another journal or other publishing venue.

- The authors have no affiliation with any organization with a direct or indirect financial interest in the subject matter discussed in the manuscript

\section{References}

1. AghaKouchak, A. (2015). A multivariate approach for persistence-based drought prediction: application to the 2010-2011 East Africa drought. J. Hydrol. 526, 127-135. doi: 10.1016/j.jhydrol.2014.09.063

2. Batisani, N. (2011). The spatio-temporal-severity dynamics of drought in Botswana. Journal of Environmental Protection, 2(06), 803.

3. Dalezios, N. R., Blanta, A., Spyropoulos, N. V., \& Tarquis, A. M. (2014). Risk identification of agricultural drought for sustainable agroecosystems. Natural Hazards and Earth System Sciences, 14(9), 2435-2448.

4. Frischen, J., Meza, I., Rupp, D., Wietler, K., \& Hagenlocher, M. (2020). Drought risk to agricultural systems in Zimbabwe: A spatial analysis of hazard, exposure, and vulnerability. Sustainability, 12(3), 752.

Page $12 / 19$ 
5. Halwatura, D., McIntyre, N., Lechner, A. M., \& Arnold, S. (2017). Capability of meteorological drought indices for detecting soil moisture droughts. Journal of Hydrology: Regional Studies, 12, 396-412.

6. Hayes, M. J., Svoboda, M. D., Wiihite, D. A., \& Vanyarkho, O. V. (1999). Monitoring the 1996 drought using the standardized precipitation index. Bulletin of the American meteorological society, 80(3), 429-438.

7. Jiao, W., Tian, C., Chang, Q., Novick, K. A., \& Wang, L. (2019). A new multi-sensor integrated index for drought monitoring. Agricultural and forest meteorology, 268, 74-85.

8. Keyantash, J. A., \& Dracup, J. A. (2004). An aggregate drought index: Assessing drought severity based on fluctuations in the hydrologic cycle and surface water storage. Water Resources Research, 40(9).

9. Keyantash, J., \& Dracup, J. A. (2002). The quantification of drought: an evaluation of drought indices. Bulletin of the American Meteorological Society, 83(8), 1167-1180.

10. Lu, X., Wang, L., Pan, M., Kaseke, K. F., \& Li, B. (2016). A multi-scale analysis of Namibian rainfall over the recent decade-comparing TMPA satellite estimates and ground observations. Journal of Hydrology: Regional Studies, 8, 59-68.

11. Massei, N., and Fournier, M. (2012). Assessing the expression of large-scale climatic fluctuations in the hydrological variability of daily Seine river flow (France) between 1950 and 2008 using Hilbert-Huang Transform. J. Hydrol. 448-449, 119-128. doi: 10.1016/j.jhydrol.2012.04.052

12. Mazdiyasni, O., and AghaKouchak, A. (2015). Substantial increase in concurrent droughts and heatwaves in the United States. Proc. Natl. Acad. Sci. U.S.A. 112, 11484-11489. doi: 10.1073/pnas.1422945112

13. McKee, T. B., Doesken, N. J., \& Kleist, J. (1993, January). The relationship of drought frequency and duration to time scales. In Proceedings of the 8th Conference on Applied Climatology (Vol. 17, No. 22, pp. 179-183).

14. Piñeiro, G., Oesterheld, M., \& Paruelo, J. M. (2006). Seasonal variation in aboveground production and radiation-use efficiency of temperate rangelands estimated through remote sensing. Ecosystems, 9(3), 357-373.

15. Räsänen, T. A., and Kummu, M. (2013). Spatiotemporal influences of ENSO on precipitation and flood pulse in the Mekong River Basin. J. Hydrol. 476, 154-168. doi: 10.1016/j.jhydrol.2012.10.028

16. Rhee, J., Im, J., \& Carbone, G. J. (2010). Monitoring agricultural drought for arid and humid regions using multi-sensor remote sensing data. Remote Sensing of environment, 114(12), 2875-2887.

17. Santos, J. F., Pulido-Calvo, I., and Portela, M. M. (2010). Spatial and temporal variability of droughts in Portugal. Water Resour. Res. 46, 1-13. doi: $10.1029 / 2009$ WR008071

18. Sheffield, J., \& Wood, E. F. (2012). Drought: past problems and future scenarios. Routledge.

19. Tsiros, E., Domenikiotis, C., Spiliotopoulos, M., \& Dalezios, N. R. (2004). Use of NOAA/AVHRR-based vegetation condition index (VCI) and temperature condition index (TCl) for drought monitoring in Thessaly, Greece. In EWRA Symposium on water resources management: risks and challenges for the 21st century, Izmir, Turkey (pp. 2-4).

20. Wang, L., d'Odorico, P., Evans, J. P., Eldridge, D. J., McCabe, M. F., Caylor, K. K., \& King, E. G. (2012). Dryland ecohydrology and climate change: critical issues and technical advances. Hydrology and Earth System Sciences, 16(8), 2585-2603.

21. Wilhelmi, O. V., \& Wilhite, D. A. (2002). Assessing vulnerability to agricultural drought: a Nebraska case study. Natural Hazards, 25(1), 37-58.

22. Wu, J., Zhou, L., Liu, M., Zhang, J., Leng, S., \& Diao, C. (2013). Establishing and assessing the Integrated Surface Drought Index (ISDI) for agricultural drought monitoring in mid-eastern China. International Journal of Applied Earth Observation and Geoinformation, $23,397-410$.

23. Xu, K., Yang, D., Yang, H., Li, Z., Qin, Y., and Shen, Y. (2015). Spatio-temporal variation of drought in China during 1961-2012: a climatic perspective. J. Hydrol. 526, 253-264. doi: 10.1016/j.jhydrol.2014.09.047

24. Yoon, J. H., Mo, K., \& Wood, E. F. (2012). Dynamic-model-based seasonal prediction of meteorological drought over the contiguous United States. Journal of Hydrometeorology, 13(2), 463-482.

25. Zhang, L., Jiao, W., Zhang, H., Huang, C., \& Tong, Q. (2017). Studying drought phenomena in the Continental United States in 2011 and 2012 using various drought indices. Remote sensing of environment, 190, 96-106.

26. Zhou, L., Zhang, J., Wu, J., Zhao, L., Liu, M., Lü, A., \& Wu, Z. (2012). Comparison of remotely sensed and meteorological data-derived drought indices in mid-eastern China. International journal of remote sensing, 33(6), 1755-1779.

\section{Figures}




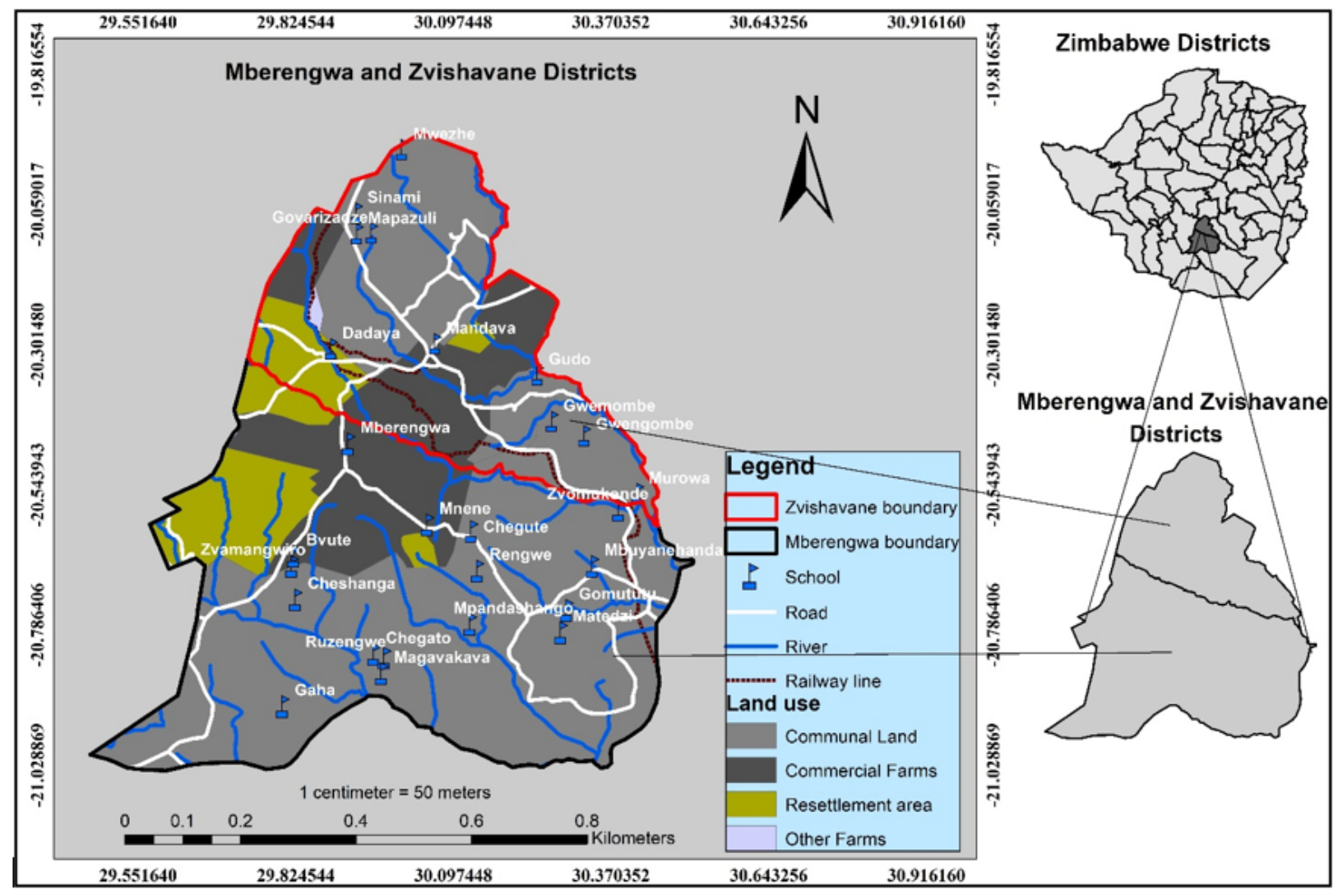

Figure 1

Map of Zvishavane and Mberengwa Districts

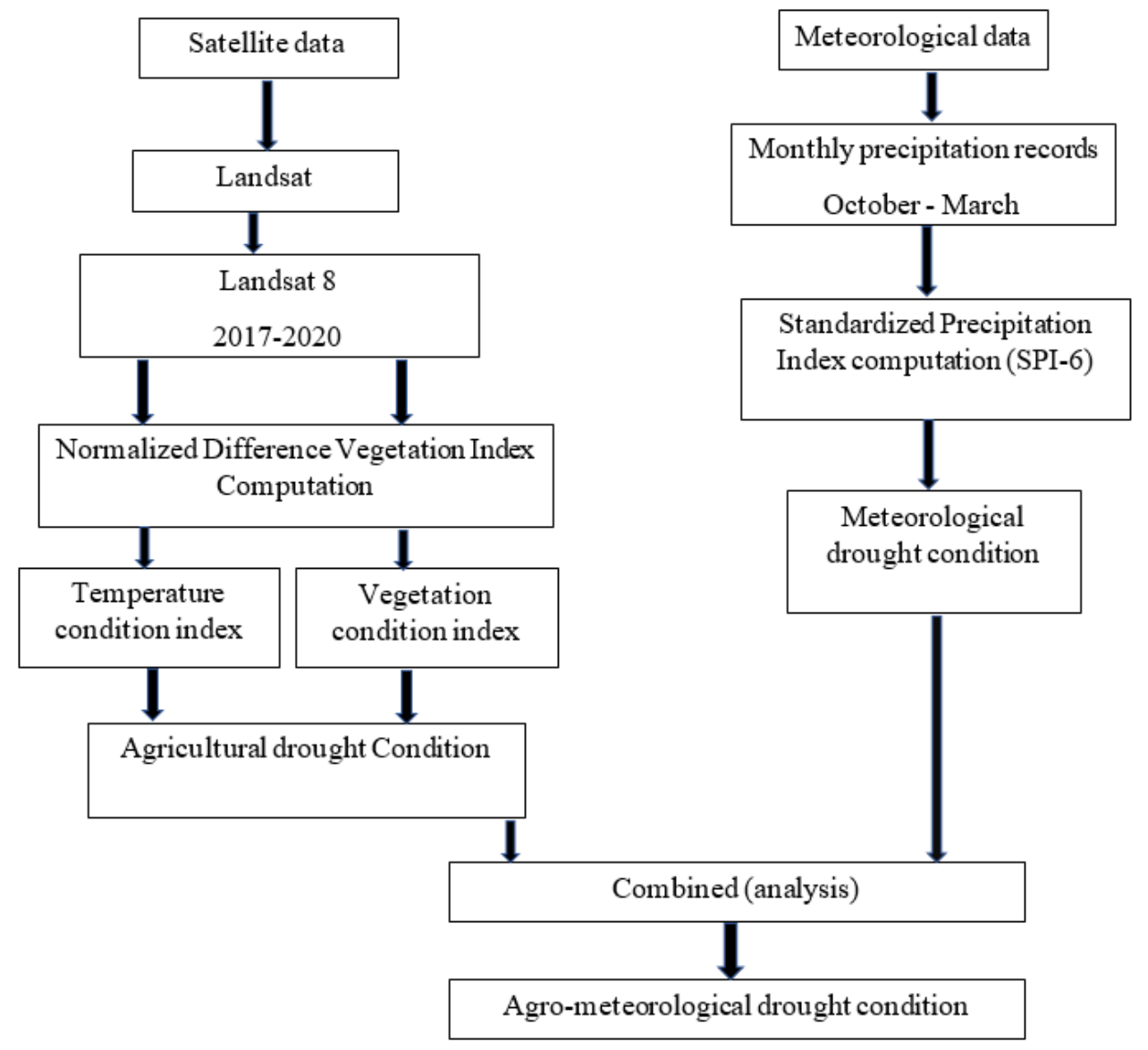

Figure 2 
Agro-meteorological drought determination procedures Source: Authors

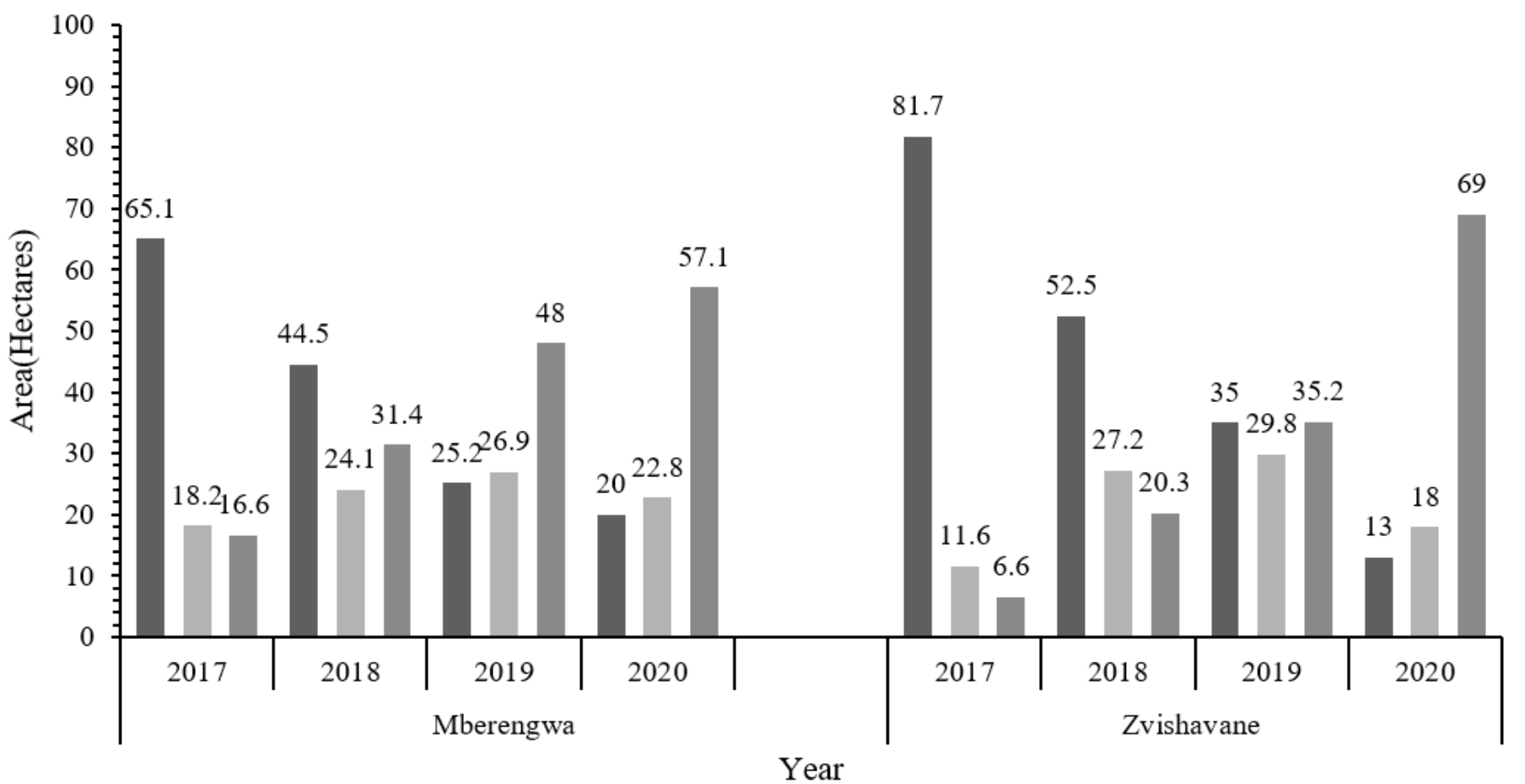

Mild-No drought $\quad$ Moderate $\quad$ Severe-Extreme

\section{Figure 3}

Temporal dynamics of VCl based drought severity between 2017 and 2020 Source: Remote sensing data

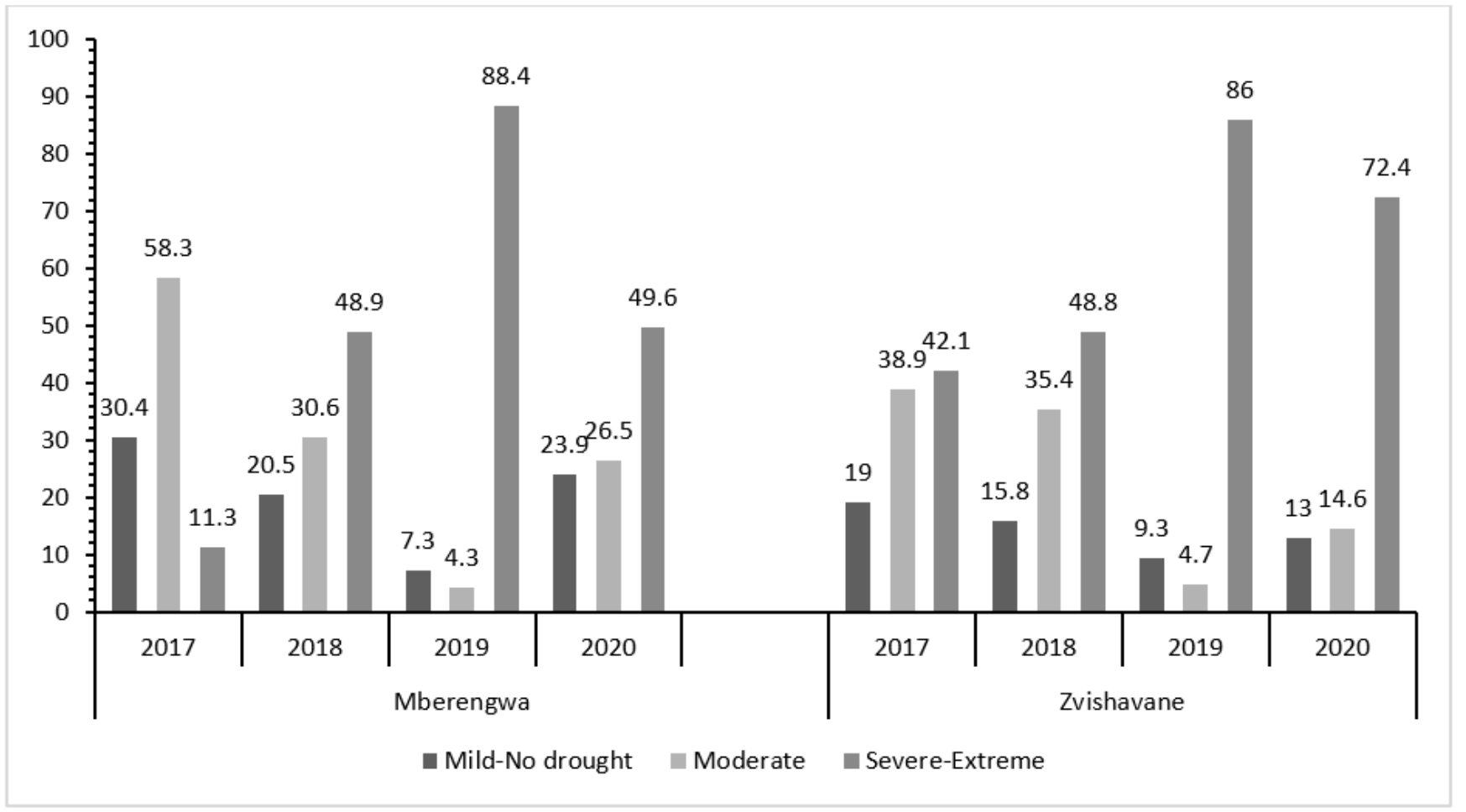

Figure 4

Temporal dynamics of TCl based drought severity between 2017 and 2020 Source: Remote sensing data 


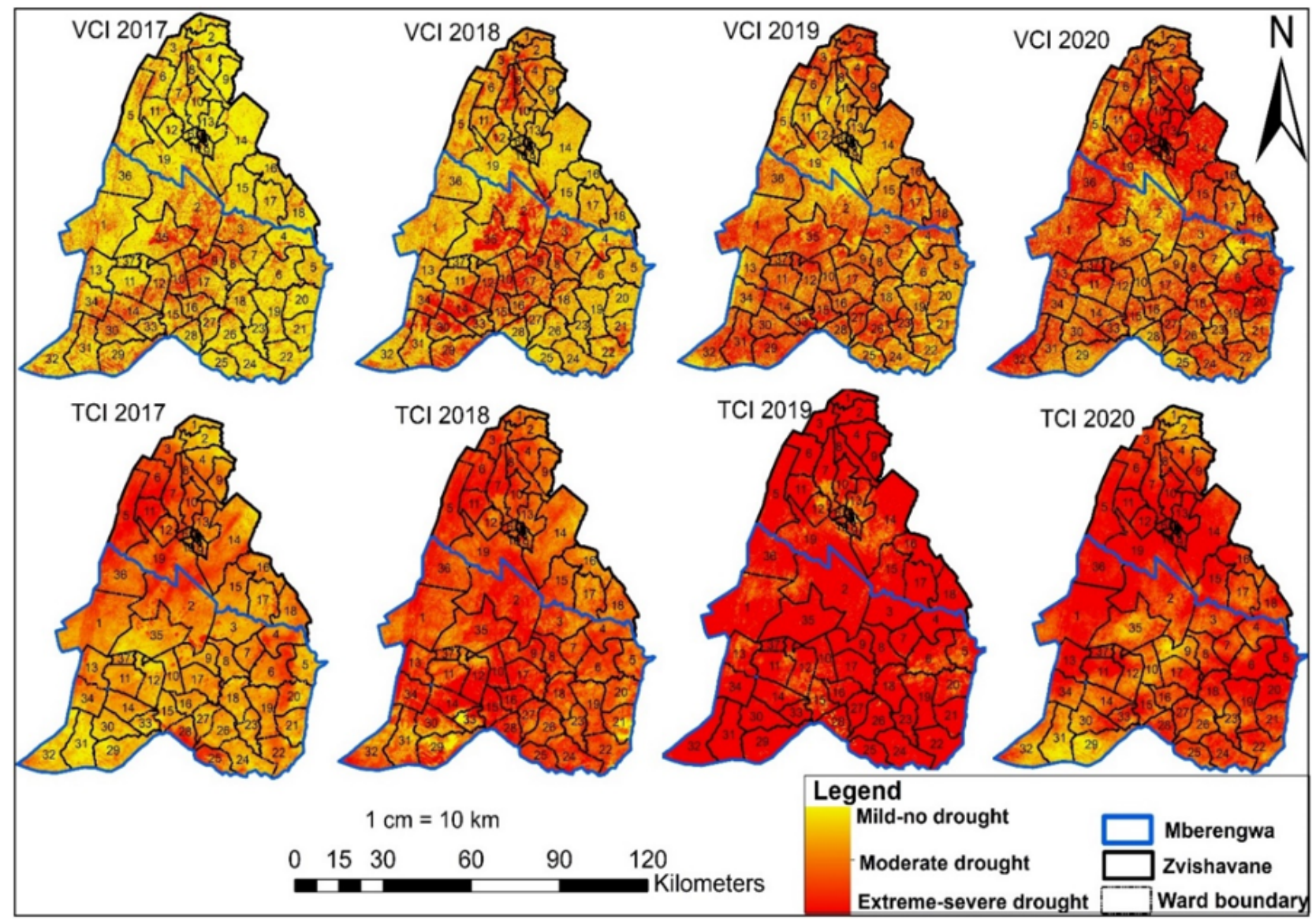

Figure 5

Ward level drought condition distribution between 2017 and 2020 Source: Remote sensing data

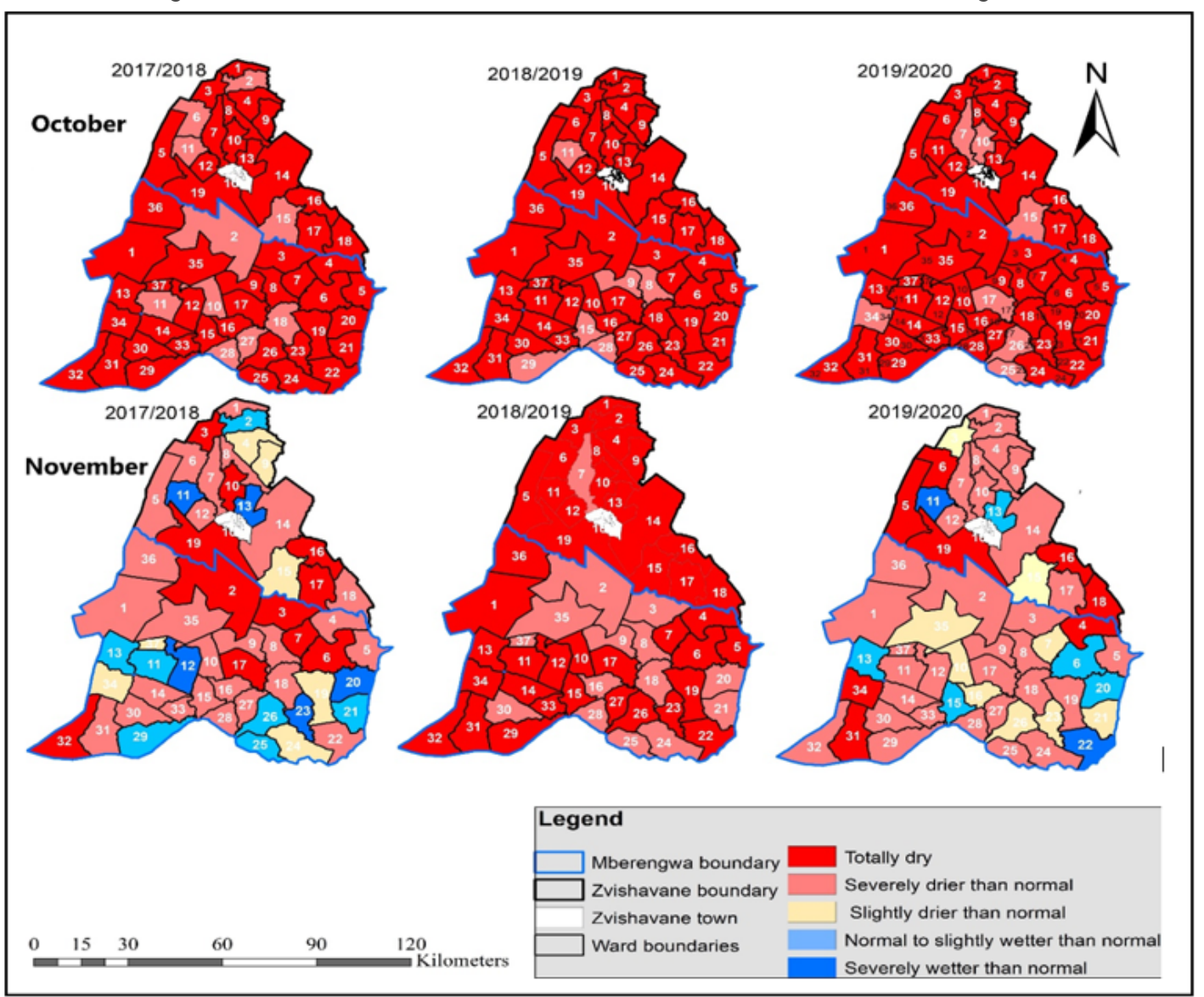




\section{Figure 6}

Ward level precipitation variability for October and November Source: Secondary data (AGRITEX)

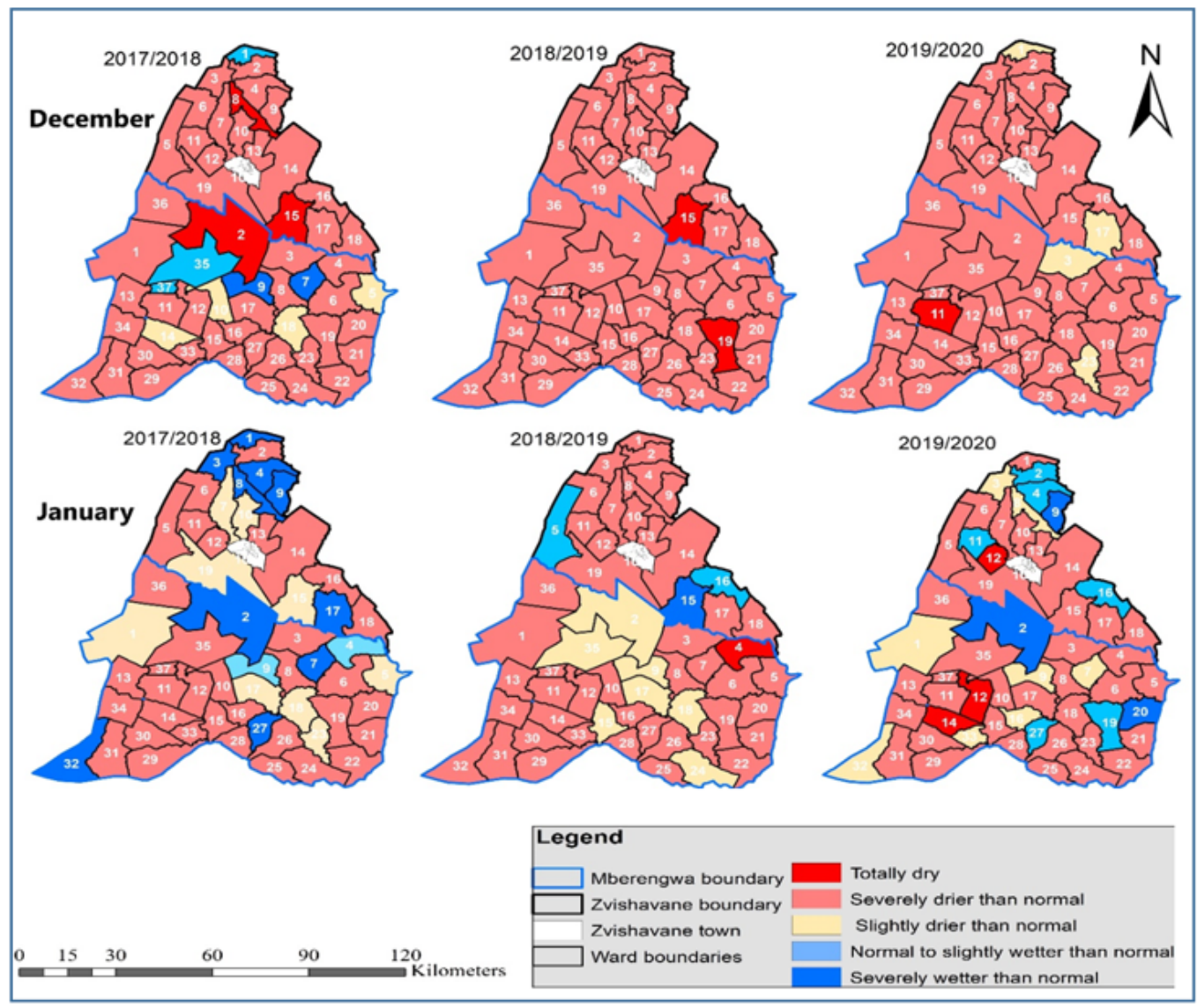

Figure 7

Ward level precipitation variability for December and January Source: Secondary data (AGRITEX) 


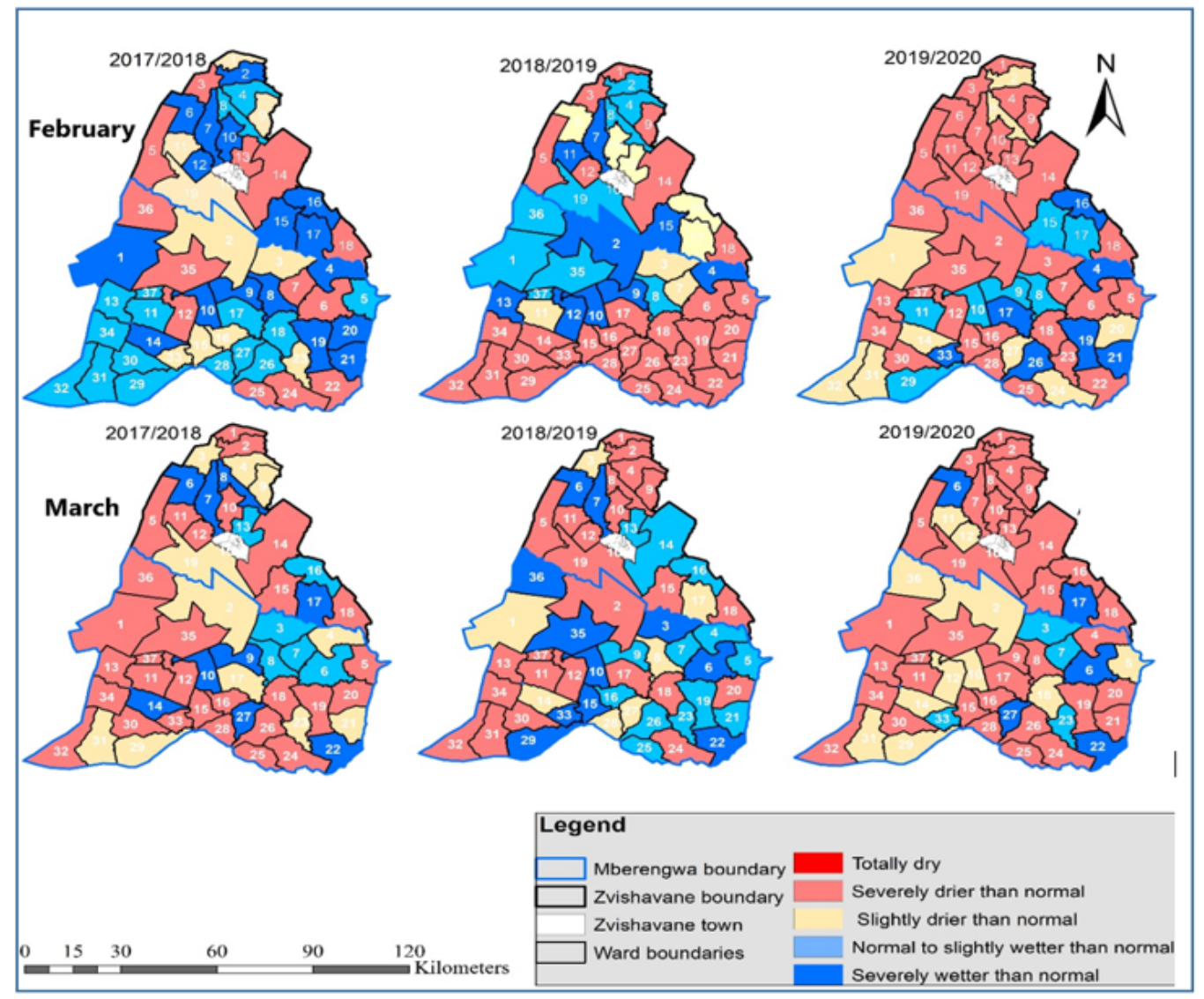

Figure 8

Ward level precipitation variability for February and March Source: Secondary data (AGRITEX)

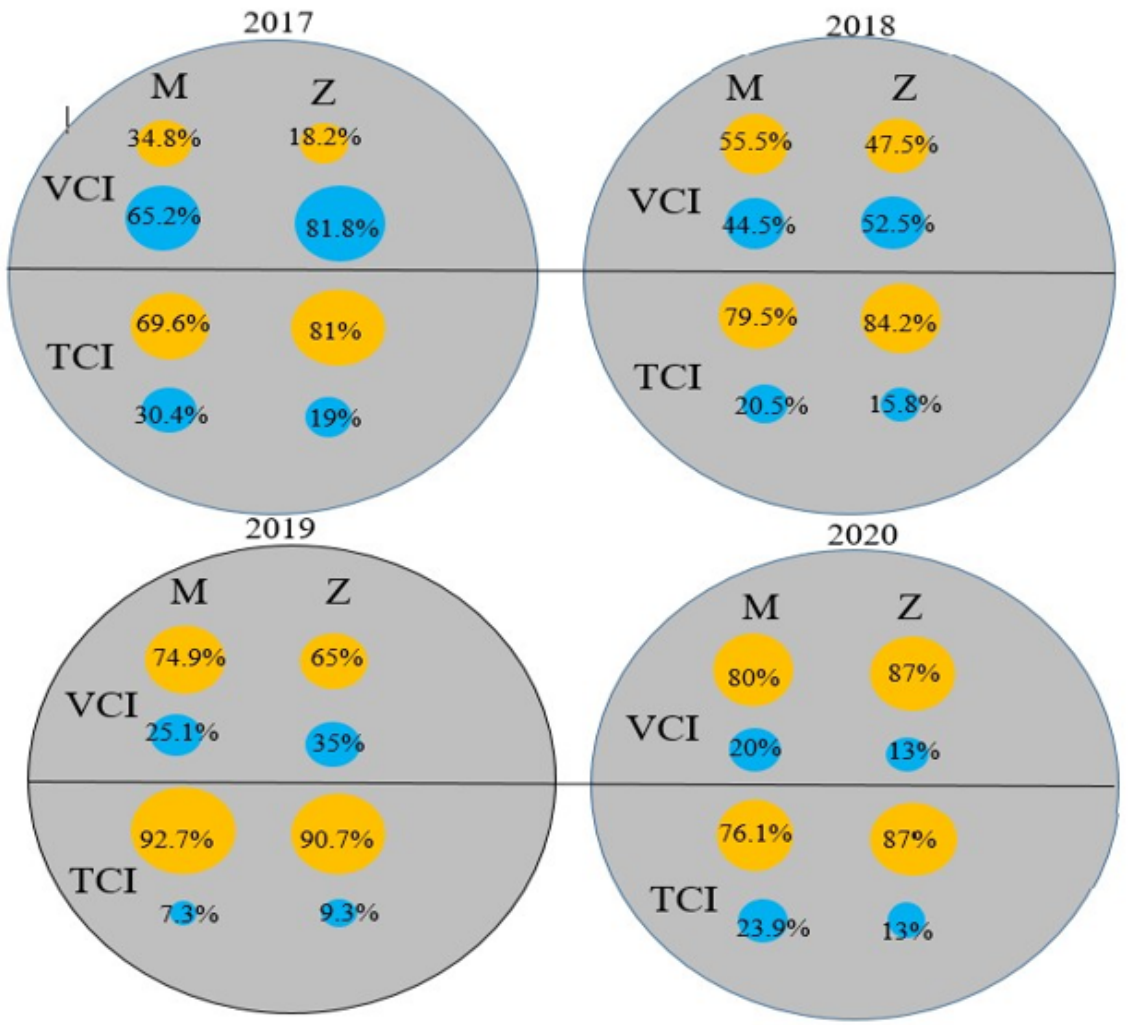

Drought

Non-drought

$\mathrm{M}=$ Mberengwa

$\mathrm{Z}=$ Zvishavane 


\section{Figure 9}

Temporal distribution of drought in Mberengwa and Zvishavane Districts between 2017 and 2020 Source: Author 